\title{
赤外線センサを用いたガラス越し鍋底温度の検出手段の検討
}

\author{
荒金 伸明 ${ }^{* 1}$ ，庄子 哲也 ${ }^{* 2}$, 花坂 照彦 ${ }^{* 2}$
}

\section{Detection means of the pan bottom temperature over the glass using the infrared sensor}

\author{
Nobuaki ARAKANE $^{* 1}$, Tetsuya SHOJI ${ }^{* 2}$ and Teruhiko HANASAKA ${ }^{* 2}$ \\ ${ }^{* 1}$ Hitachi, Ltd., Research \& Development Group \\ 832-2 Horiguchi, Hitachinaka-shi, Ibaraki 312-0034, Japan \\ ${ }^{* 2}$ Hitachi Appliances,inc. \\ 1-1-1 Higashitaga-cho, Hitachi-shi, Ibaraki 316-8502, Japan
}

\section{Received 14 March 2016}

\begin{abstract}
We studied the sensing technology that detected the pan bottom temperature through a top plate made of crystallized glass. We did the sensing with three sensors of the reflection sensor that measured the reflectance and the thermistor that agitation such as that at the top plate temperature of the thermopile and the pan bottom to detect radiant energy from the pan bottom and located it in the lower part of the top plate we were able to confirm that we could detect a different pan bottom temperature of the emittance at $\pm 10^{\circ} \mathrm{C}$ by revision of the emittance using the reflection sensor output. As for the structure of the reflection sensor, the emission of light scattered the LED emission of light with a concave lens in the pan bottom side, irradiated it, and the light receiving region with to locate in the upper part of the emission of the light region. 40-60\% of the heat agitation was included in the radiant energy that the thermopile that we placed in the lower part of the top-plate received. We were able to confirm that we could correct the heat agitation based on the correlation that we measured with the thermistor of the top-plate back side temperature and thermopile output. As a result of putting the pan bottom temperature sensing that put three sensors together on an induction cooktop, and having inspected the measurement accurately, we were able to confirm that we could detect the pan bottom temperature with an error of approximately $\pm 10^{\circ} \mathrm{C}$ in the range of $140-260^{\circ} \mathrm{C}$ regardless of the emittance of the pan bottom.
\end{abstract}

Key words : Induction cooktop, Thermopile, Infrared sensor, Temperature control

\section{1. 緒言}

結晶化ガラスなどの耐熱ガラス上に置かれた鍋を，耐熱ガラスの下方から鍋底温度を検出する温度センシング 技術を検討した．本技術の代表的な用途は，IH（Induction Heating）クッキングヒータ（米盛，2010）の鍋の温度 検出である．本研究は，実調理時における鍋底温度の検出を想定し，対象とする鍋は磁性・非磁性金属鍋とし， 鍋底 $140 \sim 250^{\circ} \mathrm{C}$ の温度検出を目的とした．従来，耐熱ガラス裏面にサーミスタ等の温度センサを密着させ，耐熱 ガラスの温度から鍋底温度を換算する手法が用いられている，サーミスタを用いた鍋底温度検出は，鍋底を長時 間一定温度で加熱するような保温条件であれば十分な精度を有している．しかしながら，板厚 $4 \mathrm{~mm}$ の而熱ガラス は伝熱速度が遅く，温度誤差が大きく，応答性が遅いという課題があった。

2008 年頃から，応答速度が数十ミリ秒と高速で検知可能な赤外線センサ（木股，2014）を用いた検出手段が実 用化されている（石丸，2010）。赤外線センサの検出素子には, 熱型のサーモパイルや量子型のフォトダイオード がある．赤外線センサは，鍋底からの放射エネルギーを基に電気信号に変換して鍋底温度を検出する．赤外線セ ンサで温度計測する場合，対象物の放射率の補正が第 1 の課題となる．また，耐熱ガラス下方からの鍋底温度検 出では，鍋からの伝熱により加熱された耐熱ガラスが外乱として含まれることから，熱外乱の補正が第 2 の課題

No.16-00095 [DOI:10.1299/transjsme.16-00095], J-STAGE Advance Publication date : 5 August, 2016

${ }^{* 1}$ 正員, (株) 日立製作所 研究開発グループ（テ312-0034 茨城県ひたちなか市堀口 832-2）

*2 日立アプライアンス（株）（テ316-8502 茨城県日立市東多賀町 1-1-1）

E-mail of corresponding author: nobuaki.arakane.wo@hitachi.com 
となる。

本研究は，鍋の反射率から放射率を換算する補正手段として，鍋の反射率を測定する反射センサの構造につい て検討した. また, 而熱ガラスの温度を検出するサーミスタを用いた熱外乱の補正手段と合わせ, サーモパイル， 反射センサ，サーミスタを組合せた鍋底温度センシングによる検出精度を検討した．

\section{2. サーミスタによる鍋底温度の検出}

結晶化ガラス製の耐熱ガラスをトッププレートとし，トッププレート裏面にサーミスタを密着させ，鍋底温度 の検出精度を検証した。 サーミスタは，温度により抵抗の值が変化する酸化物半導体材料で構成された感温抵抗 である. 図 1 にサーミスタ式鍋底温度の検出構成の概略を示す. トッププレートは，板厚 $4 \mathrm{~mm}$ である. トッププ レートの下方には誘導加熱式 IH コイルを配置しており，鍋を誘導加熱する．図 2 に IH コイルとサーミスタを配 置した IH コイルユニットの外観を示す．IH の加熱原理は，IH コイルに高周波電流を流すことでコイルの周りに 磁力線を発生させ，鍋底に磁力線が通ると，磁力線を打ち消す方向に渦電流が発生し，鍋の電気抵抗によりジュ 一ル熱を生じ, 鍋が加熱する. サーミスタはトッププレートと密着するように, IH コイル上に配置されている (庄 司，2012）ＩH コイル中心部と，中心から径方向に 50mm 離れた位置に設置した各サーミスタ 1 4 (配置は図を参 照) の温度を $\mathrm{T}_{\mathrm{t} 1} \sim \mathrm{T}_{\mathrm{t} 4}$ とした. 本試験で使用したフライパンは, 上面内径 $270 \mathrm{~mm}$, 深さ $72 \mathrm{~mm}$, 外面 (鍋底側) SUS 430 , 中層アルミ, 内面 SUS304 の三層鋼(厚み 2. 6mm)である.

図 3 にフライパンを誘導加熱した際のサーミスタ $\mathrm{T}_{\mathrm{t} 1}$ と $\mathrm{T}_{\mathrm{t} 2}$ の検出結果を示す．図中のフライパン温度は，鍋表 面に貼り付けた熱電対で測定した結果であり, 電力は電力計で測定した IH クッキングヒータの入力電力を示寸.

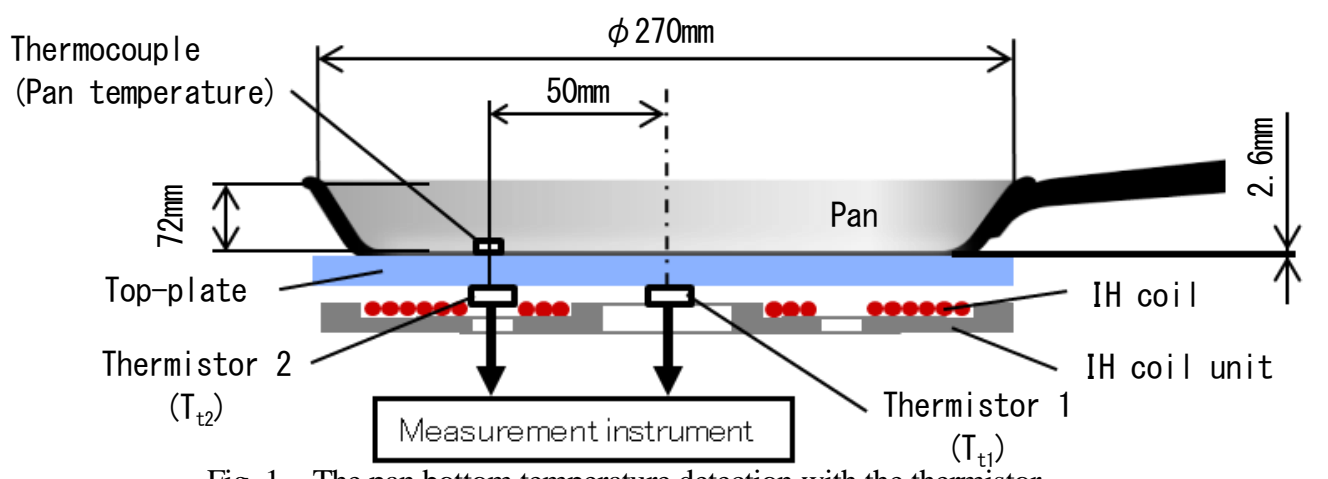

Fig. 1 The pan bottom temperature detection with the thermistor

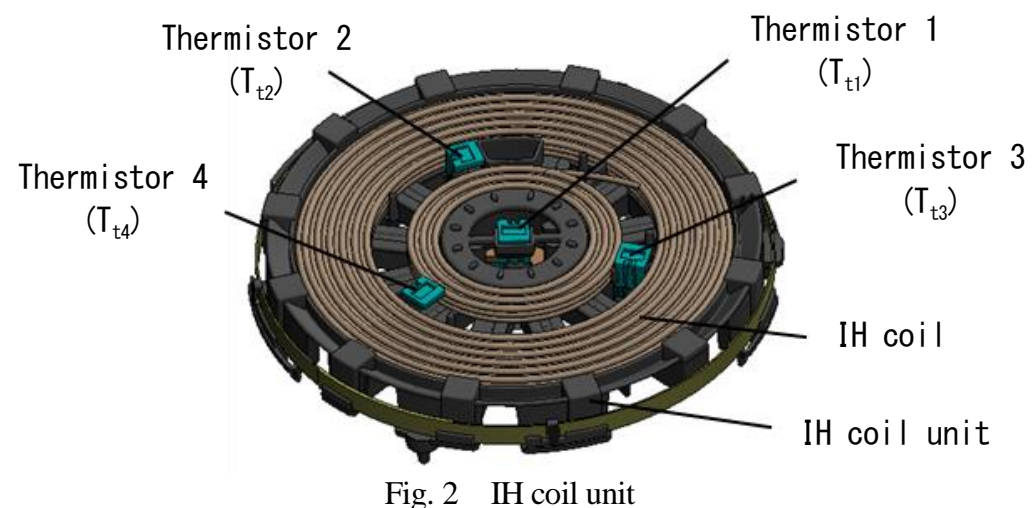

加熱開始から 2.9 分後に鍋の温度は $297^{\circ} \mathrm{C}$ よるが, トッププレート下のガラス温度は $\mathrm{T}_{\mathrm{t} 1}$ が $186^{\circ} \mathrm{C}, \mathrm{T}_{\mathrm{t} 2}$ が $202^{\circ} \mathrm{C}$ までしか達していない， $\mathrm{T}_{\mathrm{t} 1}$ と $\mathrm{T}_{\mathrm{t} 2}$ の温度差は，鍋底とトッププレートの密着状態が異なり，伝熱速度が異なるこ

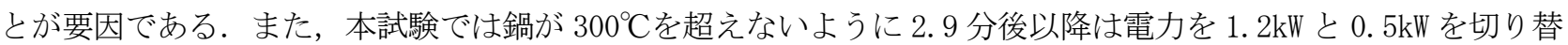
えた制御をしている. 電力切り替え時に鍋温度が $280 \sim 290^{\circ} \mathrm{C}$ で変動しているが, ガラス裏面の温度 $\mathrm{T}_{\mathrm{t} 1}, \mathrm{~T}_{\mathrm{t} 2}$ では 鍋温度の変動に追従できない. 本試験から，サーミスタに限らずガラス温度の伝熱を利用した温度検出手段では 
鍋底温度を精度良く検出することは困難である，本研究は，トッププレート下方で，鍋底から放射される赤外線 を利用する方法を検討した。

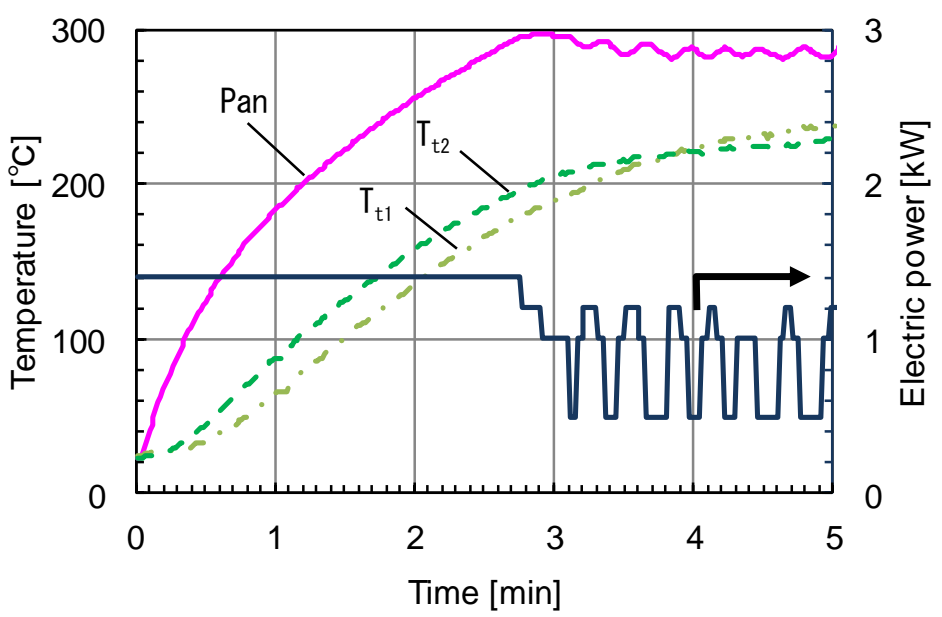

Fig. 3 Characteristic of the top-plate bottom side temperature

\section{3. 赤外線センサによる鍋底温度の検出}

図 4 に板厚 $4 \mathrm{~mm}$ の結晶化ガラス製トッププレートの分光透過特性を示寸.図中に以下の式(1)に示寸プランクの 放射則から算出される黒体の分光放射発散度 $M_{\lambda}\left[\mathrm{W} / \mathrm{cm}^{2} / \mu \mathrm{m}\right]$ と, 式(2)に示すウィーンの変移則より, ある温度で 最も強い放射エネルギーを発する波長 $\lambda_{\text {max }}[\mu \mathrm{m}]$ を記載している. 各式は第 1 放射定数 $C_{1}=37.427\left[\mathrm{~W} \cdot \mu \mathrm{m}^{4} / \mathrm{cm}^{2}\right]$, 第 2 放射定数 $C_{2}=14.388[\mu \mathrm{m} ・ \mathrm{~K}]$, 波長 $\lambda[\mu \mathrm{m}]$, 絶対温度 $T[\mathrm{~K}]$ で表せる（久野, 1994）.

$$
\begin{aligned}
& M_{\lambda}=C_{1} \times \lambda^{-5}\left[\exp \left(C_{2} / \lambda \times T\right)-1\right]^{-1} \\
& \lambda_{\max }=2897.8 / T
\end{aligned}
$$

透過率とは，特定の波長の入射光がトッププレートを通過する割合である. トッププレートの透過率は，波長 $0.4 \sim 2.9 \mu \mathrm{m}$ で 80\%以上，3〜 $4 \mu \mathrm{m}$ で最大 $55 \%$ 透過し， $4.5 \mu \mathrm{m}$ より長波，および $0.2 \mu \mathrm{m}$ より短波をカットする 特性である。

鍋底温度の検出温度帯は $140^{\circ} \mathrm{C} \sim 250^{\circ} \mathrm{C}$ であり，この温度帯の最大放射エネルギーを発する波長 $\lambda_{\text {max }}$ は式 $(2) よ$ り $5.8 \sim 7.8 \mu \mathrm{m}$ である.

図 5 にトッププレートによる黒体放射エネルギーの減衰を示寸．黑体の分光放射発散度にトッププレートの分 光透過特性を掛け合わせ，全波長域で積分して求めた。 トッププレートが無い条件の試算は，全波長域での透過

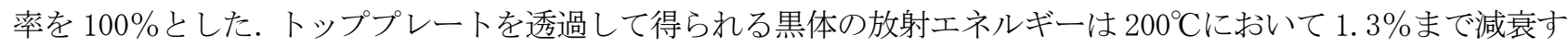
る.このためトッププレートを介した鍋底温度を検出するには高感度の赤外線センサが必要になる.

赤外線センサには量子型と熱型の検出素子がある．量子型は，半導体の素子部に入射した光子が電子と相互作 用して, 光子数に比例して電気信号を得る. 代表のセンサとしてフォトダイオードがあり, フォトダイオードは 検出素子の材料に応じて検出波長が異なる. 一般に使用される材料と検出波長は，シリコン（Si）が $0.2 \sim 1.1 \mu$ $\mathrm{m}$ ，ゲルマニウム（Ge）が 0.4 1.7 $\mu \mathrm{m}$ ，インジウム・ガリウム・ヒ素（InGaAs）が $0.8 \sim 2.6 \mu \mathrm{m}$ である（谷腰， 2012). 熱型は，放射エネルギーが入射すると受光面がわずかに昇温され，この温度変化を電気信号に変換してい る. また，可視光から赤外線の波長域 $0.38 \sim 100 \mu \mathrm{m}$ までほぼ一様な感度を有しており，代表のセンサとしてサー モパイルがある.

本研究は, 緒言で述べた鍋底温度 $140 \sim 250^{\circ} \mathrm{C}$ 温度帯の検出を目的とするため, トッププレート越しに透過す る $1.5 \sim 5 \mu \mathrm{m}$ の中赤外域の検出が必要条件となる.このことから，波長依存性を持たないサーモパイルを用いた 鍋底温度の検出手段を検討した。 


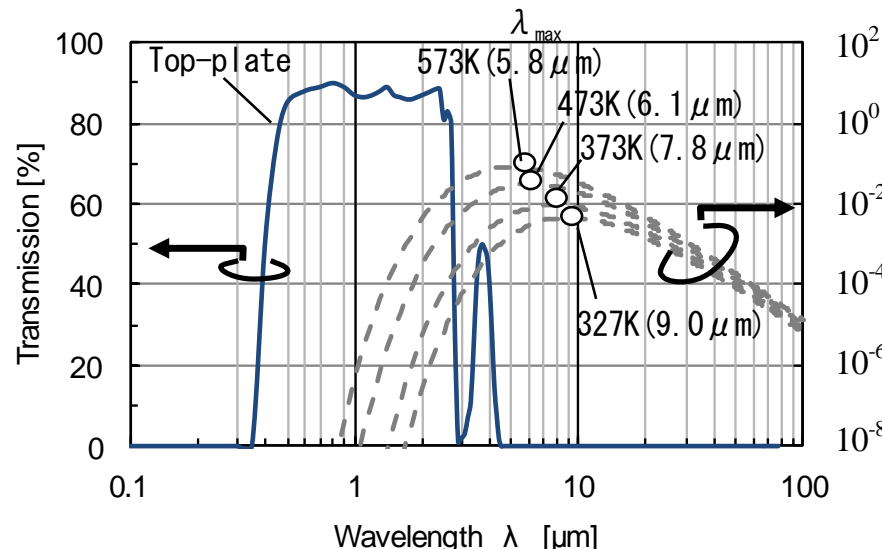

Fig. 4 Spectral transmission characteristics glass

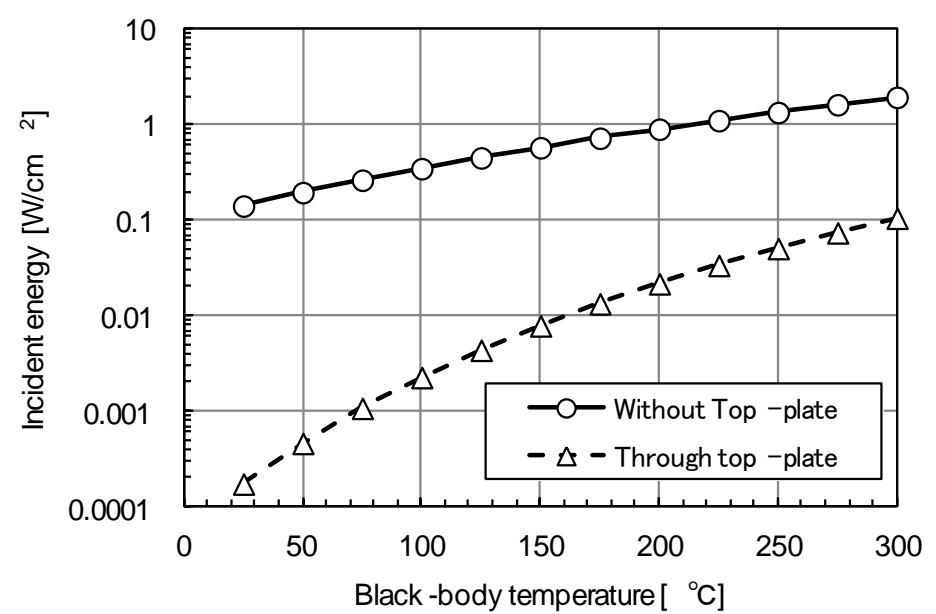

Fig. 5 Decrement of the black-body radiant energy with the top-plate

図 6 にサーモパイルを搭載したセンサ基板の外観とサーモパイル回路を示す，センサ基板は，日立アプライア

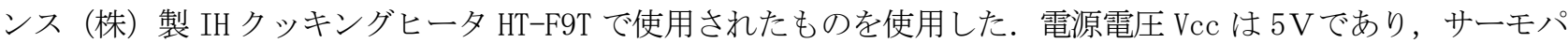
イルに内蔵されたサーミスタを用いて, $25^{\circ} \mathrm{C}$ 定常状態の基準出力電圧が $0.5 \mathrm{~V}$ となように設計している.また, トッププレートの透過特性からサーモパイルに入射する放射エネルギーは微量であることから，増幅回路で 3000 倍に増幅して出力する回路構成とした.

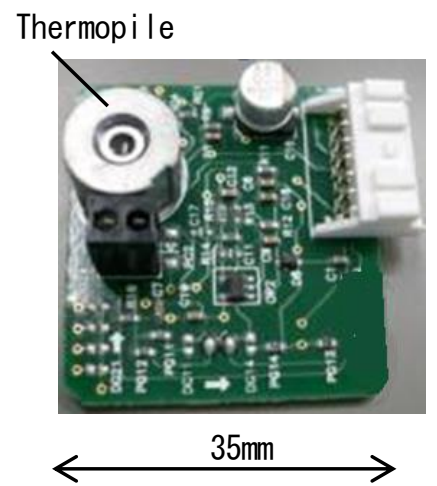

(a) Sensor board

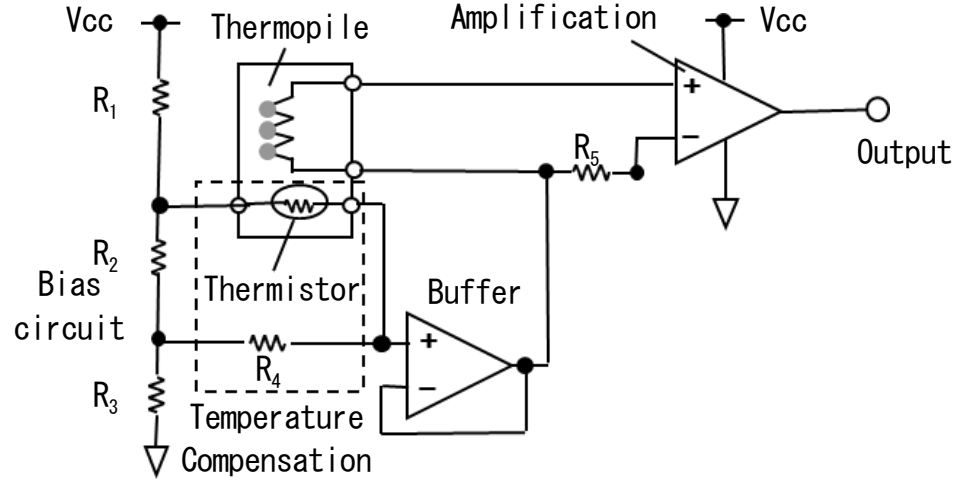

in the routine

(b) Circuit of the thermopile

Fig. 6 Constitution of the thermopile-type sensor

図 7 にトッププレート上の黒体温度とトッププレート下に配置したサーモパイル出力電圧の特性を示す.サー モパイル出力電圧は，0.5Vからのオフセット出力を示す. 試験方法は，トッププレートの下方から $48 \mathrm{~mm}$ 離した 
位置にセンサ基板を配置し，トッププレート上の黒体ヒータ温度を検出した．なお，トッププレート温度が常温 $+10^{\circ} \mathrm{C}$ 以内の条件で黒体温度を計測しており,トッププレートからの放射エネルギーの影響は無視できる.ここで, 試験に用いた黒体は放射率 $\varepsilon=0.95$ である. また, 放射率の差異を確認寸るため, 鍋底が放射率 $\varepsilon=0.7$ の鉄鍋, $\varepsilon=0.4$ の銅鍋, $\quad \varepsilon=0.3$ のアルミニウム鍋も計測して, 対象物の温度とサーモパイル出力の相関を確認した.

図に示寸様に，対象物の放射率によって，サーモパイル出力が異なることが分かる. 放射率 $\varepsilon=1.0$ の理想的な 黒体に近い黑体ヒータ（ $\varepsilon=0.95 ）$ のサーモパイル出力が最大となり, 放射率が小さくなるとサーモパイル出力も 低下寸る傾向を示寸.

物体の熱放射エネルギー $M\left[\mathrm{~W} / \mathrm{cm}^{2}\right]$ は, 放射率 $\varepsilon$, ステファン・ボルツマン定数 $\sigma\left[5.67 \times 10^{-12} \mathrm{~W} / \mathrm{cm}^{2} / \mathrm{K}^{4}\right]$, 絶対 温度 $T[\mathrm{~K}]$ から式(3)のように表せる.

$$
M=\varepsilon \times \sigma \times T^{4}
$$

このように，赤外線センサを用いて対象物の温度を測定するには放射率の補正が必要となる．放射率 $\varepsilon$ の補正 原理は, キルヒホフの放射法則より, 鍋底は金属であることから透過率 $\tau=0$, 反射率 $\rho$ とした場合式(4)で表せる.

$$
\varepsilon=1-\rho
$$

本研究では, 赤外線センサの温度検出における第 1 の課題である放射率の補正手段について, 反射率 $\rho$ を求め てキルヒホフの法則から放射率 $\varepsilon$ を得る放射率の補正手段を備えた温度センシングを構築した。

鍋底の放射率の補正では，黒体放射率を各種鍋の放射率で除算した值を反射補正係数 $K(0.95 / \varepsilon)$ と定義した. これは, 各放射率のサーモパイル出力電圧值に反射補正係数 $K$ を乗算すると黒体 (放射率 $\varepsilon=0.95$ ) のサーモパイ ル出力電圧值を換算することを意味する．鍋底の反射率に対応した放射率が設定することで，各鍋の鍋底温度を 黒体のサーモパイル出力電圧值に還元でき, この還元したサーモパイル出力電圧值から各鍋の鍋底温度の換算で きる，そのためにまず，反射率 $\rho$ を測定する反射センサを検討した.

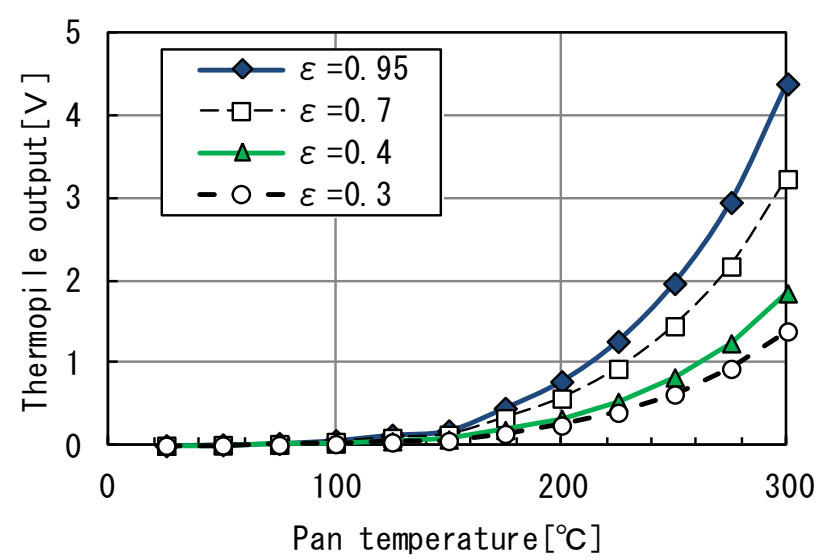

Fig. 7 The temperature of the object and the thermopile output

\section{4. 鍋底の放射率補正手段の検討}

反射センサは，赤外線発光素子 (LED: Light Emitting Diode) と受光素子（フォトトランジスタ）で構成して おり，LED の発光を鍋の裏面に照射して，鍋底からの反射光を受光した反射光量を電気信号として出力寸る. 発 光素子のピーク波長は $0.8 \sim 0.9 \mu \mathrm{m}$, 受光素子の受光感度のピーク波長は $0.85 \sim 0.9 \mu \mathrm{m}$ であり, 反射光がトップ プレートを透過する構成とした。 実調理時の鍋底温度 $140 \sim 250^{\circ} \mathrm{C}$ は, 図 4 に示すように $0.9 \mu \mathrm{m}$ より長波長側で あることから，鍋底温度と反射センサの発光波長域が異なる構成とした。この構成によりサーモパイルの鍋底温 度の検出に当たり, 反射センサの発光の影響は無い. 
反射センサの配置は表 1 に示寸ようにサーモパイルに隣接させており，サーモパイルの検出位置と同等となる ように配置した。

鍋底は，凹凸形状や污れなど，検出領域の状態に応じて鍋底から戻る反射光量が異なる．特に反射センサの鍋 底検出面積が小さいとわずかな污れなどにより反射センサ出力が影響し，放射率を正しく補正できなくなる．こ のため，反射センサによる鍋底の検出面積を拡大し，鍋底の形状や污れなどの影響を緩和する目的で 4 方式の反 射センサを用いて，発光の照射面積と検出精度の関係を検討した.

表 1 に 4 方式の反射センサの概略を示す．I，II 型は発光・受光共に砲弾型素子を組合せた構成としており， 素子外径を $\phi 2.2 \mathrm{~mm}$ と $\phi 3.0 \mathrm{~mm}$ として, その差異を比較した. III型はアルミ蒸着した凹面鏡で LED 発光を表面に反 射させて鍋底に照射させ，受光は凹面鏡の側面に配置する構成とした．発光部と受光部は各々周囲を筒で覆い， 受光部に LED 光が直接入射しない構成としたＩV型は凹面鏡発光部の上方に受光素子を配置し，受光素子の周囲 を筒で覆い, LED 光が直接入射しない構成とした.

図 8 に鍋底の反射センサ出力を計測した試験構成を示寸。ここで, トッププレートは板厚 $4 \mathrm{~mm}$ であり, トップ プレートの下方に，サーモパイルと反射センサを搭載したセンサ基板を樹脂製のケースに収納に配置している. トッププレートとセンサ間には，放射エネルギーと反射センサの光路として幅 $22 \mathrm{~mm} \times$ 奥行き $13 \mathrm{~mm}$ の導光筒を設 置した，導光筒内部は黒色に塗装し，反射光の乱反射を防いでいる．センサ基板を収納した樹脂ケースの上面は 開口しており, サーモパイルと反射センサの上方に板厚 $2 \mathrm{~mm}$ の結晶化ガラス製光学フィルタをはめ込んでいる.

Table 1 The outline of a reflection sensor

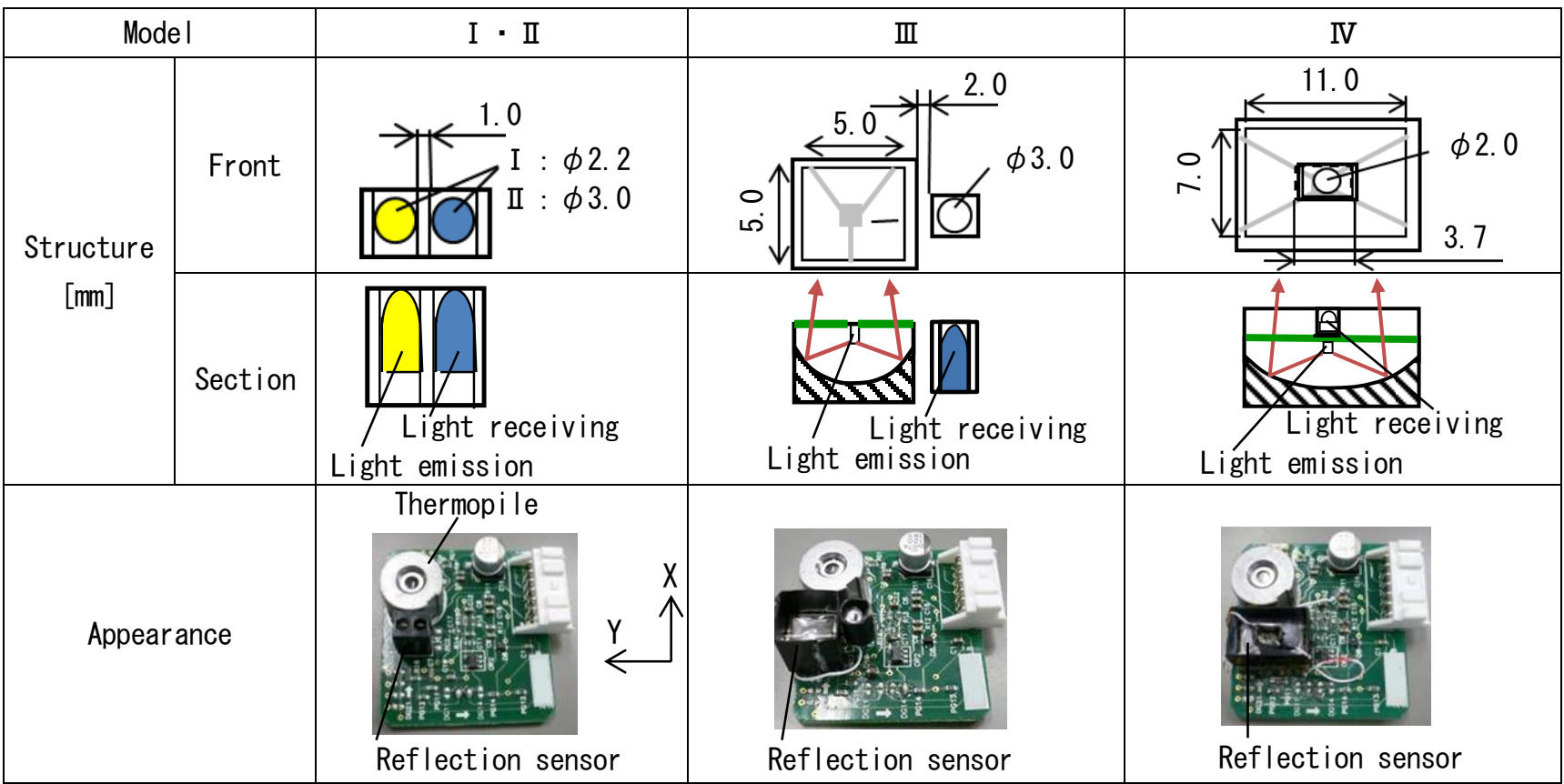

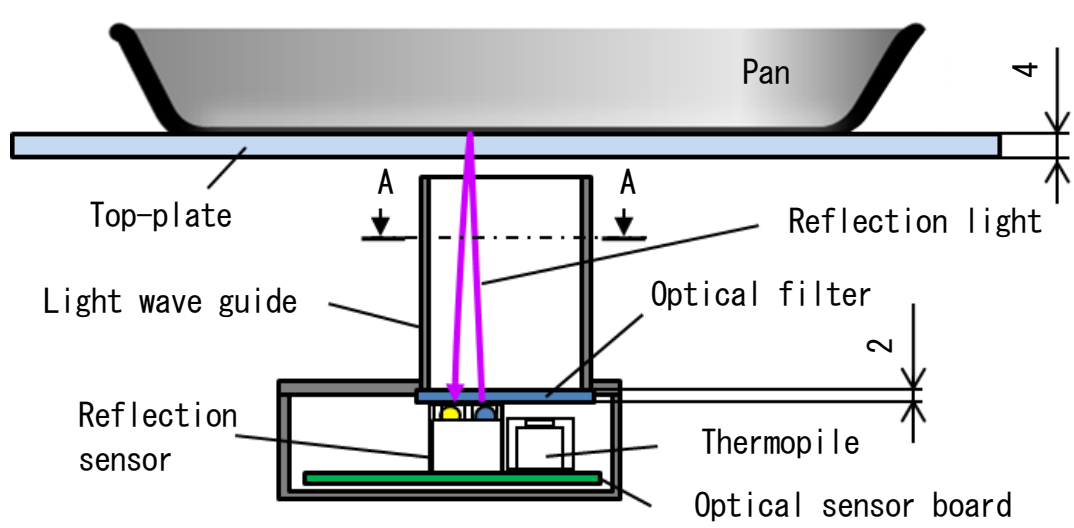

Unit : mm

Fig. 8 Examination constitution of the reflection sensor

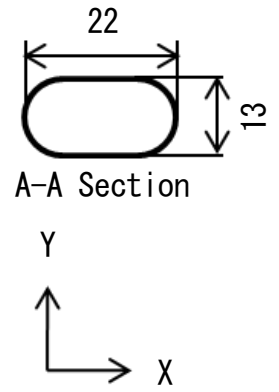


次に，反射センサが検出する鍋底面の領域を測定した試験の概要を説明する．プラスチック板全面にアルミテ 一プを貼り, 図 8 に示したX, Y 方向に分けて, 長さ $30 \mathrm{~mm}$ の黒体テープを最少幅 $1 \mathrm{~mm}$ から $1 \mathrm{~mm}$ 刻みで最大幅 $8 \mathrm{~mm}$ までの 8 種類の異なる黒体テープを貼り付けた。これを図 8 の導光筒上のトッププレートに, 反射センサの中心 軸上に黒体幅の中心が位置するように配置して反射センサ出力電圧を測定した.

図 9 に全アルミテープの反射センサ出力を 1 とした場合, 各黒体幅での反射センサ出力の比率を示寸.ここで, 反射センサ出力比の下限值は 0.5 と設定した. 反射センサ出力比の下限值 0.5 以下では，黒体と放射率の低い $\varepsilon$ $=0.4$ などの反射センサ出力電圧と，電圧差が小さく放射率の補正が困難となるため下限值を設定した．Ｉ， II 型 の砲弹型素子は，X，Y 方向ともに黒体幅 $1 \mathrm{~mm}$ 以上で反射センサ出力の比率が 0.55 以下となり，検出領域は $1 \mathrm{~mm}$ 以下であった，凹面鏡を用いた照射方式では，III型よりIV型で検出領域が拡大する結果を得たＩV型の凹面鏡照 射型における反射センサ出力の比率は黒体幅 $3 \mathrm{~mm}$ 検出領域 $9 \mathrm{~mm}^{2}$ で，X 方向に $0.62 ， Y$ 方向に 0.9 であった. IV型 の受光素子の配置を凹面鏡の上方に配置したことで，鍋底に照射した反射光を効率良く集光できた．反射センサ 出力比 0.5 以上を満足する I, II 型の砲弹型素子の検出領域は $1 \mathrm{~mm}^{2}$ であり, IV型の凹面鏡照射型の検出領域は I, II 型の砲弾型素子の検出領域と比べ 9 倍まで拡大したことになる.

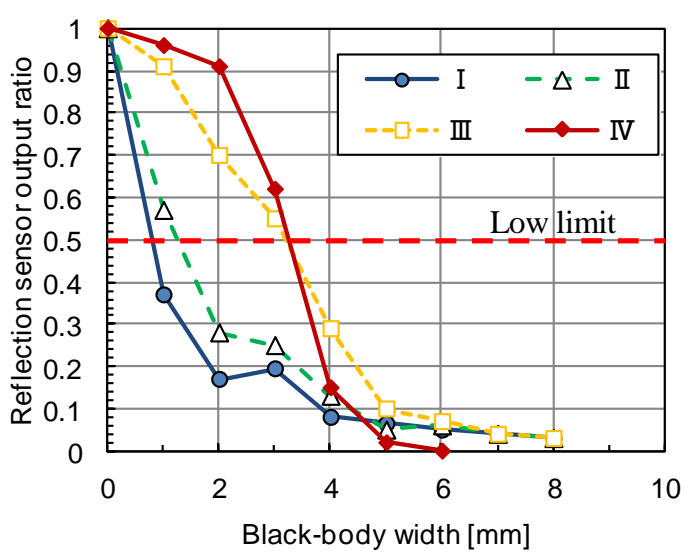

(a) $\mathrm{X}$ direction

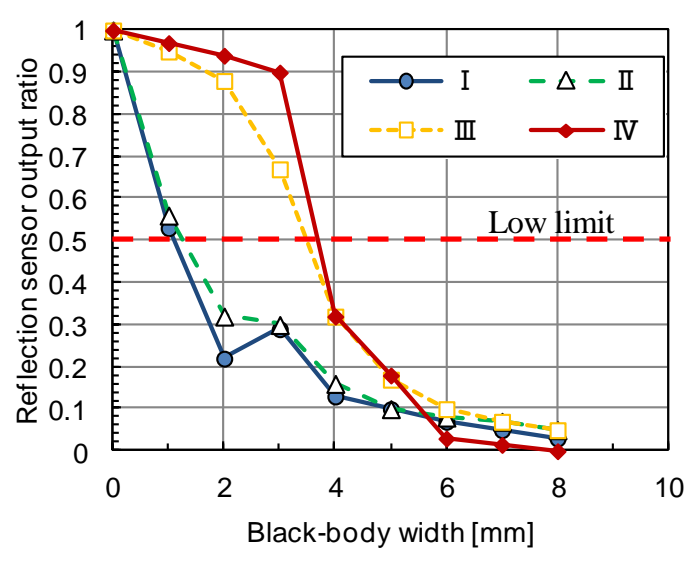

(b) Y direction

Fig. 9 The reflection sensor output for the black body width

次に，表 1 に示寸 $\mathrm{I}$ 型と $\mathrm{IV}$ 型のセンサ基板により，反射センサ出力と反射補正係数 $K$ の測定精度を評価した. なお，反射補正係数 $K$ を式(5)で定義する.

$$
K=\left(V R_{1}-V_{1 \_25}\right) /\left(V R-V_{1 \_25}\right)
$$

ここで, 放射率 $\varepsilon=0.95$ の黒体を貼付けた鍋のサーモパイル出力電圧 $V R_{1}[\mathrm{~V}]$, 測定鍋のサーモパイル出力電圧 $V R[\mathrm{~V}], 25^{\circ} \mathrm{C}$ のサーモパイル出力電圧 $V_{1 \_25}[\mathrm{~V}]$ である. 試験方法は, $200^{\circ} \mathrm{C}$ 加熱した鍋をトッププレートに置き, 鍋底温度 $200^{\circ} \mathrm{C}$ のーモパイル出力電圧 $V R$ と反射センサ出力電圧を測定した.

表 2 は試験で使用した鍋の一覧で, 全て IHクッキングヒータで使える鍋である.鍋の形状は鍋 1 のみ両手鍋で, 他は全て片手鍋のフライパンである．また，鍋 1 ～9 は磁性体金属，鍋 10１2 は非磁性体金属の鍋である.

図 10 に, 反射センサの測定精度を検証した試験結果を示す. 図 10 (a) は, 表 2 の全ての鍋を使用して反射セン サ出力電圧と式(5)で求めた反射補正係数 $K$ を測定した結果である. 図 10 (b) は，プラスは鍋底温度が高いことを 意味する．鍋底温度 $200^{\circ} \mathrm{C}$ と反射補正係数 $K$ から換算した鍋温度との測定差を示す.

図 10 (a) に測定結果を示す，各種鍋の測定結果を 3 次曲線で近似し，実測值と近似曲線との相関を表す決定係 数 $\mathrm{R}^{2}$ 值を用いて評価した.ここでは, $\mathrm{R}^{2}$ 值が 1 に近づくほど測定精度が優れると判断した. $\mathrm{R}^{2}$ 值は, I 型で 0.68 , IV型で 0.87 であることから, 各種鍋の測定結果においてもIV型の反射センサの方が, 反射補正係数 $K$ の測定精度 が高い.このため本研究では, 本試験で得た近似曲線を用いて, 反射センサ出力の值から反射補正係数 $K$ を求め た. 
Table 2 Specifications of the pan for the examination

\begin{tabular}{|c|c|c|c|c|c|c|c|c|c|c|c|c|}
\hline No. & 1 & 2 & 3 & 4 & 5 & 6 & 7 & 8 & 9 & 10 & 11 & 12 \\
\hline $\begin{array}{c}\text { Dimensions in } \\
\text { the upper } \\
\text { part [mm] }\end{array}$ & $\phi 235$ & $\phi 260$ & $\phi 260$ & $\phi 270$ & $\begin{array}{c}140 \\
\times 195\end{array}$ & $\phi 240$ & $\phi 240$ & $\phi 260$ & $\phi 280$ & $\begin{array}{c}\phi 26 \\
0\end{array}$ & $\begin{array}{c}\phi 27 \\
0\end{array}$ & $\phi 240$ \\
\hline $\begin{array}{c}\text { Depth } \\
{[\mathrm{mm}]}\end{array}$ & 80 & 50 & 55 & 72 & 30 & 59 & 55 & 58 & 55 & 50 & 58 & 40 \\
\hline $\begin{array}{c}\text { Materials of } \\
\text { the pan }\end{array}$ & \multicolumn{7}{c|}{ Iron } & \multicolumn{8}{c|}{ Stainless steel, aluminum multi layer } & Aluminum & Copper \\
\hline
\end{tabular}

図 10 (b) は，フライパンの取っ手が試験装置の手前側に配置した状態を基準 $0^{\circ}$ とし，時計周りに鍋を 45 度毎 に回転させて計 8 回測定し, 鍋温度 $200^{\circ} \mathrm{C}$ に対する反射補正係数 $K$ で補正した換算温度との誤差を表している. 試験方法は，鍋温度 $200^{\circ} \mathrm{C}$ のサーモパイル出力電圧 $V R$ と反射センサ出力電圧を測定し，図 10 (a) の近似曲線を用 いて反射センサ出力電圧から反射補正係数 $K$ を求め, 式 (6) より鍋底温度 $200^{\circ} \mathrm{C}$ 換算出力電圧 $V R_{3 \_200}$ を求め, 温 度換算した. 試験は表 2 の鍋 3 [反射補正係数 $K=1.6$ （放射率 $\varepsilon=0.63 ）$ ]を使用した. 鍋 3 は内径が $\phi 260 \mathrm{~mm}$ と 2 章の試験で使用したフライパンよりも小径であるが材質は同じである.

$$
V R_{3 \_200}=\left(V R-V_{1 \_25}\right) \times K
$$

図 10 (b) より温度誤差は， I 型が-16〜 $+15^{\circ} \mathrm{C}, \mathrm{IV}$ 型が-8〜 $+7^{\circ} \mathrm{C}$ であった. IV 型の鍋底面の検出領域 $\left(9 \mathrm{~mm}^{2}\right)$ は I 型の場合の $1 \mathrm{~mm}^{2}$ よりも拡大したことで, 鍋底面の污れや凹凸形状に係わらず温度誤差 $110^{\circ} \mathrm{C}$ 以内で検出できるこ とが分かった.

上記結果から，I 型のような砲弾型素子を並列に配置した構成の反射センサに比べて，IV型の凹面鏡照射構成 とする反射センサは，鍋底面の状態に関わらず，反射補正係数 $K$ を精度良く測定でき，鍋底面の放射率の補正に 優れていることを確認できた.

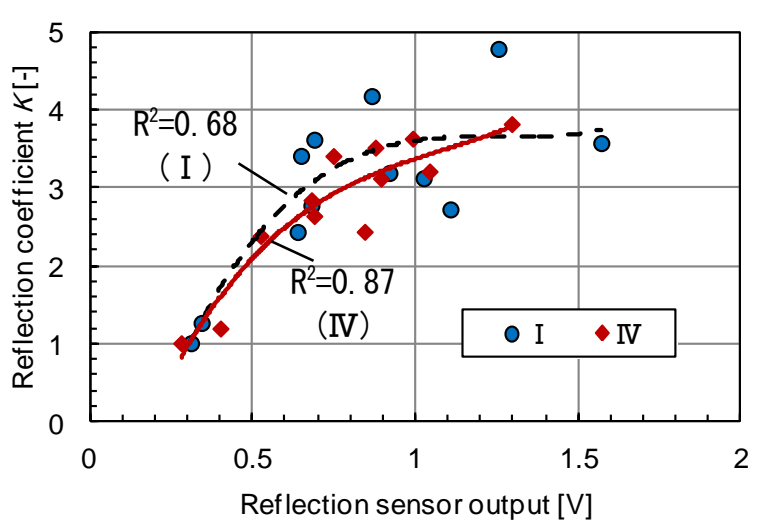

(a)Reflection coefficient $K$

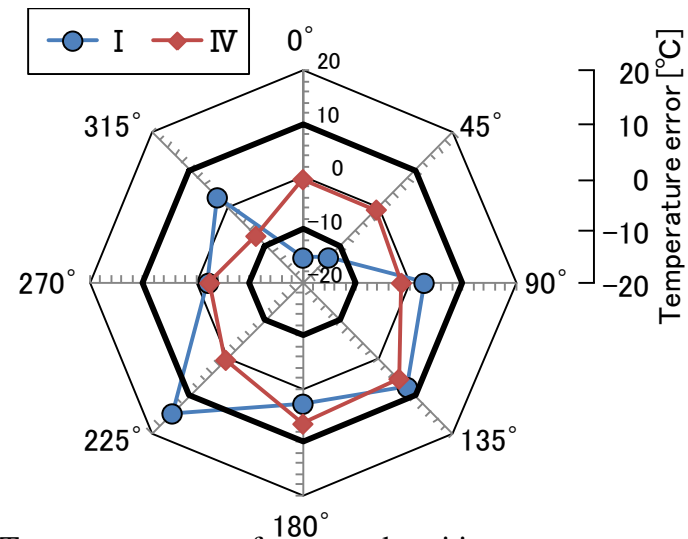

(b)Temperature error of measured positions

Fig. 10 Measurement accuracy of the reflection sensor

\section{5. 鍋底温度センシングシステムの検討}

\section{$5 \cdot 1$ センシングシステムの構成}

図 11 に，サーモパイル，反射センサ及びサーミスタ（図 2 の $\mathrm{T}_{\mathrm{t} 2}$ ）の 3 種類のセンサを組合せた鍋底温度セン シング（荒金，2013）の構成を示す．板厚 $4 \mathrm{~mm}$ の結晶化ガラス製トッププレートの下方には，鍋を加熱する IH コイルを配置している.さらに IH コイルの下方にサーモパイルと反射センサを搭載したセンサ基板を樹脂製のケ 一スに収納している. ここで, 本構成のトッププレート上面とセンサ基板上面の間隔は $48 \mathrm{~mm}$ であり, トッププレ 
一トとセンサ間には導光筒を設置しており，センサ基板への IH コイルから輻射熱を遮熱する効果も有している. 試験で使用したサーモパイルの視野特性は基準出力 50\%感度で士11 度であり，視野角土11 度では導光筒の温度 を検出しない. センサ基板を収納した樹脂ケースの上面は開口しており，サーモパイルと反射センサの上方に，4 章と同一の板厚 $2 \mathrm{~mm}$ の光学フィルタをはめ込んでいる. 光学フィルタには鍋からの放射エネルギーを透過し，ト

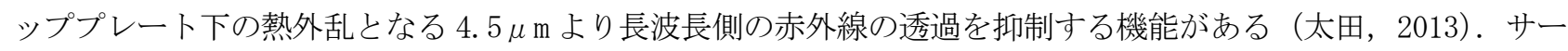
ミスタはトッププレート董面に密着させており, 半径 $100 \mathrm{~mm}$ の IH コイル対し, 図 1 で示したようにサーモパイル とサーミスタは中心から $50 \mathrm{~mm}$ に配置した。

図 12 に鍋底温度センシング搭載した IH クッキングヒータの外観を示す. IH ヒータは左・右・中央の 3 か所に 搭載しており, 今回の試験では右側 IH コイルに本研究の鍋底温度センシングを設置した. トッププレートに設け たセンサ空には印刷を施さず，鍋底からの放射エネルギーをトッププレート下方に透過する構成とし，センサ空 を介して鍋底温度の検出精度を検討した。

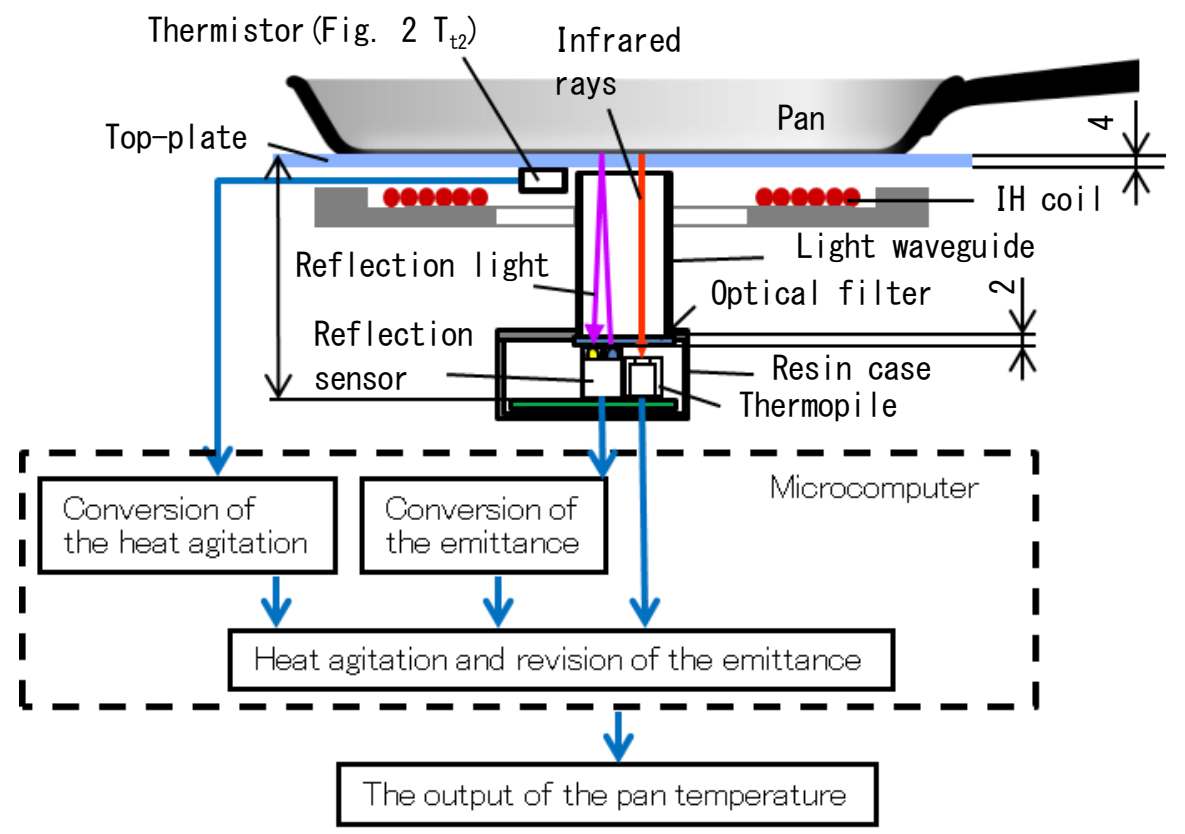

Fig. 11 Pan-bottom temperature sensing system

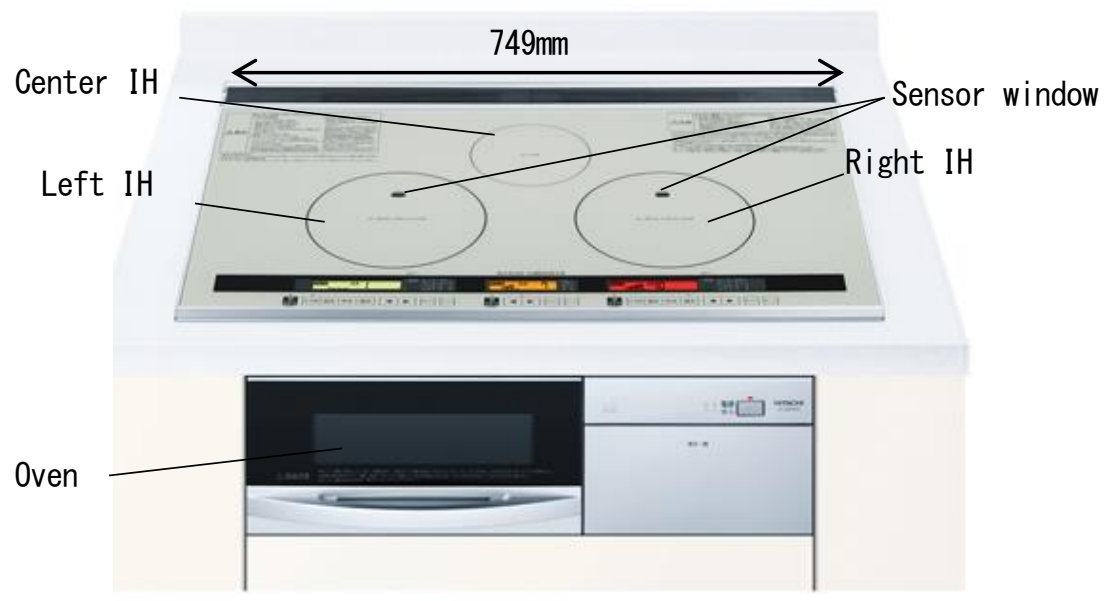

Fig. 12 Induction Cooktop

4 章のIV型の反射センサを用いた反射補正係数 $K$ と，後述する 5.2 節のトッププレート温度補正によるサーモ パイル出力電圧 $V_{n}$ を用いて, 鍋底温度と温度換算で求めた温度との測定誤差を評価した. 鍋底温度の換算出力電 圧 $V R_{3}[\mathrm{~V}]$ を式(7)に，鍋底の換算温度 $t\left[{ }^{\circ} \mathrm{C}\right]$ を式(8)に示す. 


$$
\begin{aligned}
V R_{3} & =\left[\left(V R-V_{1-25}\right)-V_{n}\right] \times K \\
t & =f\left(V R_{3}\right)
\end{aligned}
$$

ここで, 鍋底の換算温度 $t\left[{ }^{\circ} \mathrm{C}\right]$ は, 反射補正係数 $K$ とトッププレート温度補正電圧 $V_{n}$ で補正した鍋底の換算出 力電圧 $V R_{3}[\mathrm{~V}]$ に対応した温度換算表から求めている.

\section{$5 \cdot 2$ 熱外乱の補正手段の検討}

次に，赤外線センサの温度検出における第 2 の課題である熱外乱の補正手段を説明する．熱外乱とは，鍋底か らの伝熱や IH コイルからの輻射熱により加熱されたトッププレートからの放射エネルギーである.この熱外乱は, IH クッキングヒータで鍋を加熱中に, トッププレートから鍋を外した状態のサーモパイル出力電圧 $V_{n}$ で表すこ とができる. サーモパイル出力電圧 $V_{n}$ は， $25^{\circ} \mathrm{C}$ サーモパイル出力電圧 $V_{1 \_25}[\mathrm{~V}]$ からのオフセット出力電圧を用 いた. 熱外乱分のサーモパイル出力電圧 $V_{n}$ は, トッププレート裏面温度を測定しているサーミスタの測定温度と 相関付けて設定した. サーモパイル出力電圧 $V_{n}$ とサーミスタ測定温度を相関付けることで, 熱外乱の補正量を導 き出せる，なお本補正は，以後トッププレート温度補正と呼び，トッププレート温度補正量を以下の試験方法で 求めた.

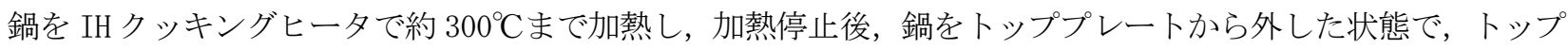
プレートが室温付近まで泠却されるまでのサーミスタ温度とサーモパイル出力電圧を測定した.

IH クッキングヒータは, 冷却ファンを備えており, この冷却ファンは鍋の加熱中および停止中において, イン バータ回路や IH コイルが所定の温度に冷却されるまで動作している．本試験で使用した IH クッキングヒータで は加熱する鍋により冷却風量 $Q$ の設定を変更しており, 磁性体金属鍋で $1.2 \mathrm{~m}^{3} / \mathrm{min}$, 非磁性体金属鍋で $2.1 \mathrm{~m}^{3} / \mathrm{min}$ であった。このためトッププレートの温度補正量は，冷却ファンの冷却風量 $Q$ に合わせてトッププレート温度補 正量を測定し，結果を図 13 に示寸.

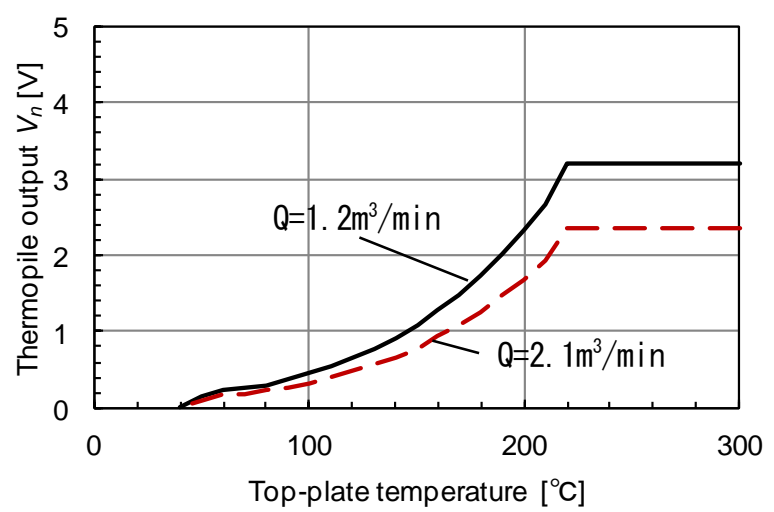

Fig. 13 Revision properties of the top-plate temperature

サーモパイル出力 $V_{n}$ は冷却風量 $Q$ に応じて異なり, トッププレート温度が $50^{\circ} \mathrm{C}$ から $220^{\circ} \mathrm{C}$ にかけて上昇する.

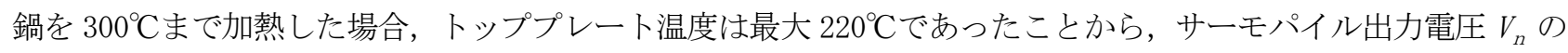
最大值を $220^{\circ} \mathrm{C}$ 值 $\left(\mathrm{Q}=1.2 \mathrm{~m}^{3} / \mathrm{min}\right.$ で $V_{n}=3.2 \mathrm{~V}, \mathrm{Q}=2.1 \mathrm{~m}^{3} / \mathrm{min}$ で $\left.V_{n}=2.4 \mathrm{~V}\right)$ としている. 非磁性体金属鍋の 運転モード $2.1 \mathrm{~m}^{3} / \mathrm{min}$ の方が，トッププレートや IH コイルに対する冷却性能が高く，本体内部の発熱が抑えら れ, サーモパイル出力電圧 $V_{n}$ は小さい.

ここで, 熱外乱の補正効果を検証するため, サーモパイルに入射した鍋底からの放射エネルギー率(鍋分エネル ギー率 $Q_{P}[\%]$ ) と, 鍋底以外のトッププレートなどからの放射エネルギー率(外乱エネルギー率 $Q_{d}[\%]$ ) を求めた. 鍋分エネルギー率 $Q_{P}$ は鍋底温度の換算出力電圧 $V R_{3}[\mathrm{~V}]$ から式(9)で表せ, 外乱エネルギー率 $Q_{d}$ は式(10)で表す ことができる. 


$$
\begin{aligned}
& Q_{P}=\left(V R_{3} / K\right) /\left(V R-V_{1 \_25}\right) \times 100 \\
& Q_{d}=V_{n} /\left(V R-V_{1 \_25}\right) \times 100
\end{aligned}
$$

試験では，表 2 に示す鍋 3 の底面に反りが無い鍋反り $0 \mathrm{~mm}$ の物と，底面が上方側に反り，トッププレートと底 面に $2 \mathrm{~mm}$ の隙間を生じた鍋反り $2 \mathrm{~mm}$ の物の 2 種類を使用した. 図 14 に鍋底保温制御時における鍋分エネルギー率 $Q_{P}$ を示す. 図中 (a) は鍋反り $2 \mathrm{~mm}$ の鍋保温制御時の各エネルギー率の経時変化を示し, 図中 (b) は各温度設定でト ッププレートの裹面温度変化が $\pm 1{ }^{\circ} \mathrm{C}$ 変化量に安定した 1 分間の鍋分エネルギー率 $Q_{P}$ の平均值示す.

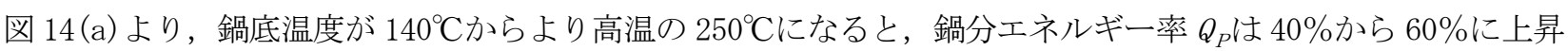
し，外乱の影響が小さくなる．図 5 に示したように対象物が高温であるほどトッププレートを透過する入射エネ

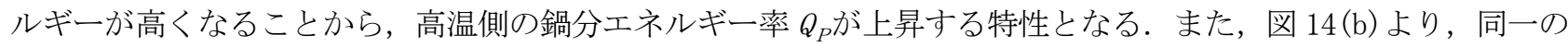
鍋底温度に対して鍋反りが $0 \mathrm{~mm}$ と $2 \mathrm{~mm}$ で鍋分エネルギー率 $Q_{P}$ が異なる. 鍋反りが $0 \mathrm{~mm}$ の場合, 鍋底とトップレー トが密着しておりトッププレート温度が $2 \mathrm{~mm}$ の鍋反りよりも高温となり，外乱エネルギー率 $Q_{d}$ が増し，鍋分エネ ルギー率 $Q_{P}$ が 10\%低下した。このように鍋とトッププレートの接触状態により外乱エネルギー率 $Q_{d}$ の比率が変 動する.

サーモパイルが受光した入射エネルギー量の 40～60\%は外乱エネルギー率 $Q_{d}$ であることから，IH クッキング ヒータでの鍋底温度の検知精度向上には，熱外乱補正が必要である.

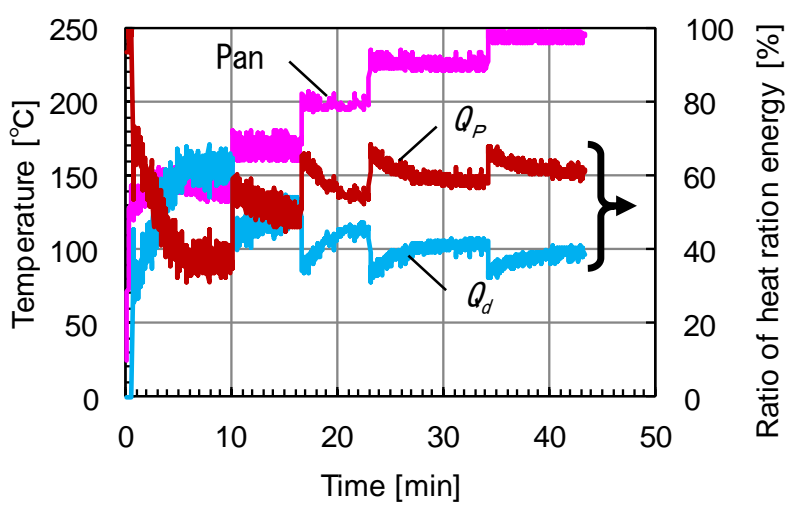

(a)Ratio of $Q_{P}$ and $Q_{d}$

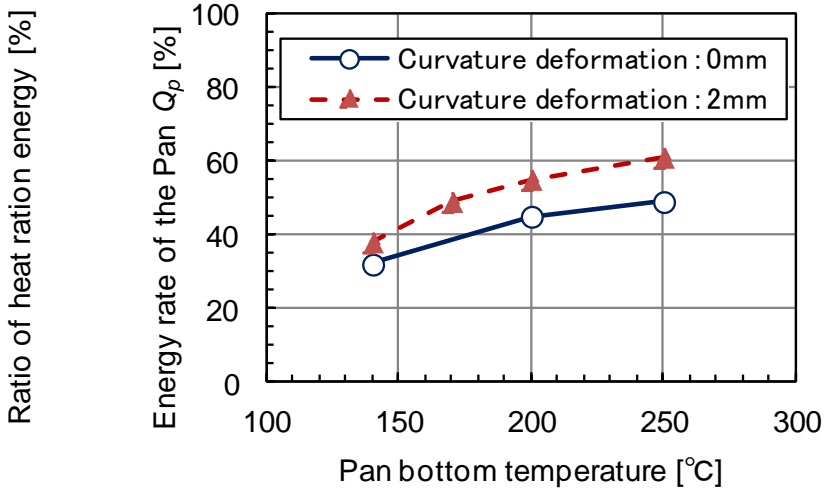

(b)Ratio of $Q_{P}$

Fig. 14 Ratio of heat radiation energy under "the temperature control cooking" mode

\section{$5 \cdot 3$ 鍋底温度の検出精度}

鍋底温度の換算は図 11 に示すように，IH クッキングヒータ内蔵のマイクロコンピュータ（以下，マイコン） で処理した. サーモパイル，反射センサ，サーミスタの出力電圧を $\mathrm{AD}$ 変換した值をマイコンに入力し，サーモパ イル出力電圧から熱外乱エネルギーを補正後，放射率を補正し鍋温度を計算した。

試験方法は電力 $800 \mathrm{~W}$ での鍋加熱と, 鍋底温度を $140^{\circ} \mathrm{C}$ で保温制御する 2 種類の加熱及び制御方法で鍋底温度と 換算温度の誤差を評価した。図 15 に本試験で使用した鍋底の外観を示す。図に示す様に $K=1.0$ は放射率 $\varepsilon=0.95$ の黒体テープを貼り付けている. $K=1.6$ は污れが付着しており，表面の放射率は不均一である．なお，K=2.5 は新 品である. 図 16 に試験結果を示す. 図 16 (a) は, 電力 800W の加熱試験結果である. 対象鍋は表 2 の鍋 3 とし, 鍋底の反射補正係数 $K=1.0,1.6,2.5$ と異なる 3 種類を用いた. また, 放射率の補正が無いセンシング構成で $K=1.6$ の鍋底を測定した結果も示している．鍋底温度 $200^{\circ} \mathrm{C}$ 時は，放射率の補正が無いと温度誤差 $30^{\circ} \mathrm{C}$ あった。 3 種 類の反射補正係数 $K$ で各温度帯の温度誤差が士 $10^{\circ} \mathrm{C}$ 以内で収まっている. 従って， 凹面鏡照射によるIV型反射セ ンサにより，鍋底の污れなどに係わらず放射率を補正できた。

上記結果より，凹面鏡照射の反射センサを用いた反射補正係数 $K$ とトッププレート温度補正を組合せた鍋底温 度センシングにより，トッププレートを介する $140 〜 250^{\circ} \mathrm{C}$ 鍋底温度を精度良く測定できることが確認できた. 


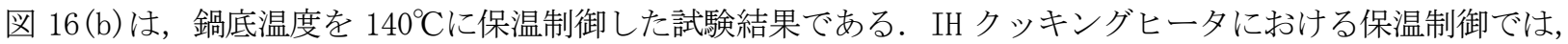
マイコンで出力した鍋温度を基に，IH コイルに入力する電力を自動制御している. 試験方法は，IHコイルにより

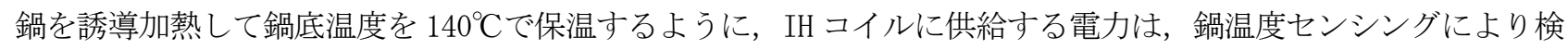

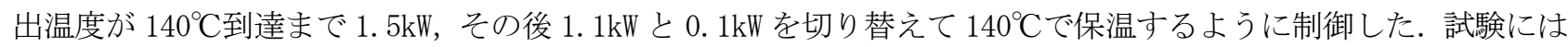
表 2 の反射補正係数 $K=1.6$ の鍋 3 を用いた.

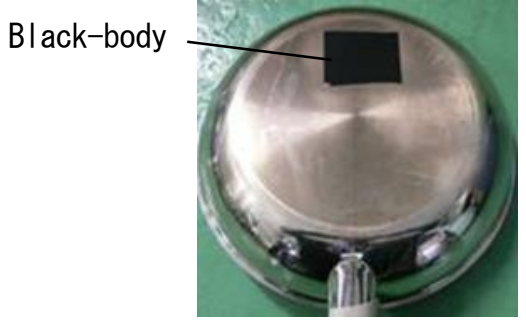

$K=1.0$

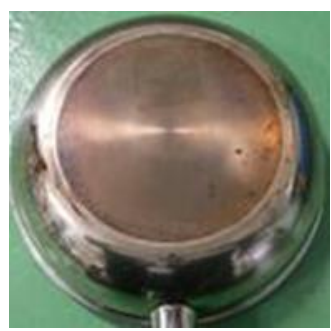

$K=1.6$

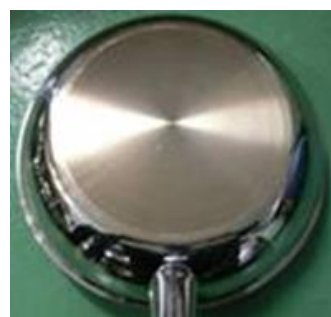

$K=2.5$

Fig. 15 Pan-bottom for examinations

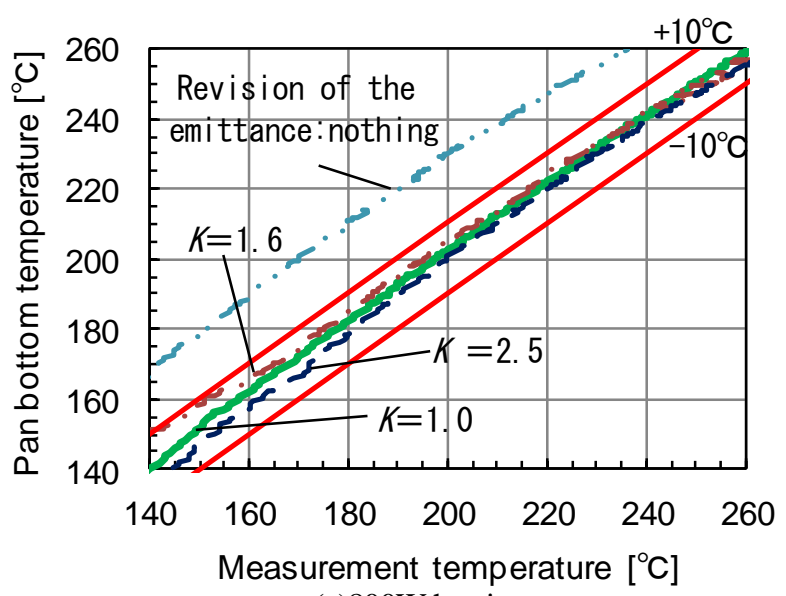

(a) $800 \mathrm{~W}$ heating

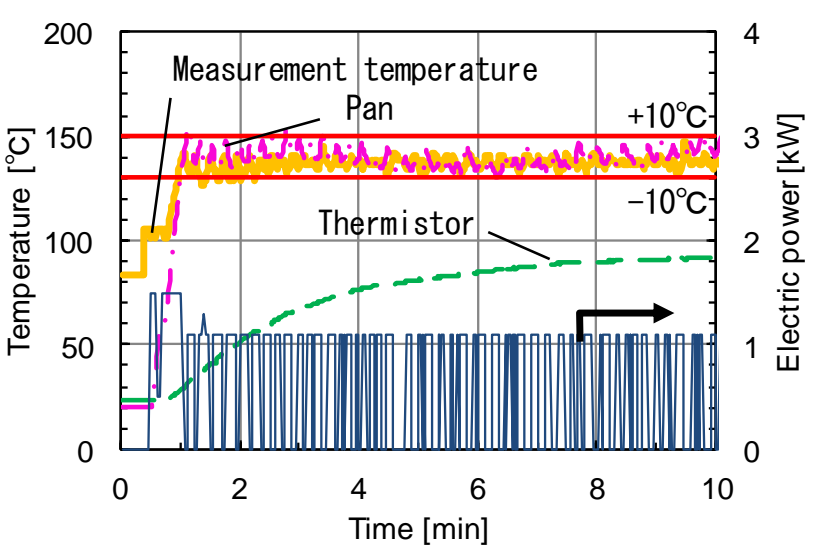

(b) $140^{\circ} \mathrm{C}$ temperature control

Fig. 16 Measurement accuracy of the pan bottom temperature

サーモパイルを用いた鍋温度センシングは，鍋底温度が $140^{\circ} \mathrm{C}$ 到達時から保温時においても土 $10^{\circ} \mathrm{C} て ゙$ 鍋底温度 を検出できた．トッププレート董面のサーミスタでは，鍋底温度と温度誤差 $50^{\circ} \mathrm{C}$ 上であり，鍋底の温度変化に 追従できないことが分かる，上記より，サーモパイル，反射センサ及びトッププレート温度などの外乱を補正す

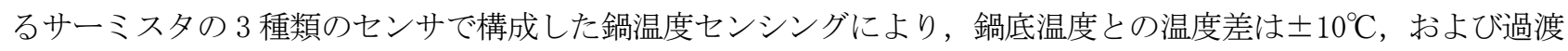
的な温度変化にも追従できる.

\section{6. 結 言}

結晶化ガラス製のトッププレート越しに鍋底温度を検出するセンシング技術の開発を行い, 以下の結論を得た. (1) センシングの構成は，鍋底からの放射エネルギーを検出するサーモパイル，鍋底の反射率を測定する反射セ ンサ, 及びトッププレート温度などの外乱エネルギーを補正するサーミスタの 3 種類のセンサとし，トッププ レート下方に配置した。

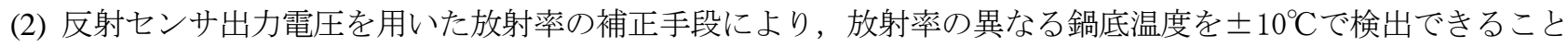
を確認できた. 反射センサの構造は，発光部は LED 発光を凹面鏡で鍋底面に拡散して照射し，受光部は，発光 部の上部に配置する構成とし, 発光素子から直接照射する反射センサの構成に比べ検出面積を 9 倍に拡大でき ることが分かった。 
(3) トッププレート下方に配置したサーモパイルが受光する放射エネルギーには 40 〜 $60 \%$ の熱外乱エネルギーが 含まれており, サーミスタで計測したトッププレート裹面温度とサーモパイル出力の相関を基に, 熱外乱エネ ルギーを補正できることが確認できた.

（4）３センサを組み合わせた鍋底温度センシングを IH クッキングヒータに搭載して測定精度を検証した結果，鍋

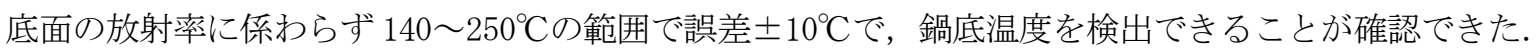

\section{文献}

荒金伸明，火加減上手なオールメタル対応 IH クッキングヒータ，日本機械学会誌，Vol.116， No. 1132（2013）, pp. $28-29$.

石丸直昭，ビルトイン IH クッキングヒータの進化，日本 AEM 学会誌，Vol. 18, No. 3 (2010), pp. 185-190.

木股雅章，赤外線センサ，電気学会論文誌 E，Vol. 134，No.7（2014)，pp. 193-198.

久野治義, 赤外線光学, 電子情報通信学会, (1994)， pp. 2-23.

太田義注, 誘導加熱調理器, 特許 5135386 (2013).

庄司浩幸，IH 調理機器における最新技術，電気学会誌，Vol. 132, No. 8(2012), pp. 545-547.

谷腰欣司，センサーのしくみ，電波新聞社，（2012）, pp. 28-90.

米盛弘信, IH クッキングヒータの技術背景と研究動向, 日本 AEM 学会誌，Vol. 18, No. 3(2010), pp. 179-184.

\section{References}

Arakane, N., The induction cooktop with double all-metal compatibility which is good at control of heat, Journal of the Japan Society of Mechanical Engineers, Vol.116, No.1132 (2013), pp.28-29(in Japanese).

Ishimaru, N., Evolution of induction heating cookers, Journal of the AEM, Vol.18, No.3(2010), pp.185-190(in Japanese).

Kimata, M., Infrared sensor, IEEJ Transactions on Sensor and Micromachines E, Vol.116, No.1132(2013), pp.28-29 (in Japanese).

Kuno,H., Infrared engineering, The Institute of Electronics, Information and Communication Engineers (1994), pp.2-23(in Japanese) .

Ohta, Y., Induction heating cooking device, Japanese patent disclosure 5135386(2013) .

Shoji,H., Latest technology in the IHcooking apparatus , Journal of the IEEJ, Vol.132, No.8 (2012), pp.545-547(in Japanese).

Tanikoshi, K. , The institute of electronics, Dempa publications,Inc (2012), pp.28-90(in Japanese) .

Yonemori,H., Technological background and study trend on the IH cooking heater , Journal of the AEM, Vol.18, No.3 (2010), pp.179-184(in Japanese). 